\title{
Mapping interpersonal violence against women in the District of Nias, 2009-2016
}

\author{
Pemetaan kekerasan antarpribadi terhadap perempuan di Kabupaten Nias \\ tahun 2009-2016
}

\author{
Mita Yesyca, Formas Juitan Lase \& Nenny Anggraini \\ Center for Women's Studies of Universitas Kristen Indonesia \\ Jalan Mayjen Sutoyo No. 2, Cawang, Kramat Jati, East Jakarta 13630 \\ E-mail: mita.yesyca@uki.ac.id
}

\begin{abstract}
The research is about mapping interpersonal violence against women in the Nias District, North Sumatera. The patriarchal culture which has a hold in the area has significant effects on women. Using a social mapping approach and a feminist perspective, data in this research were collected through literature study, i.e. reports of service provider institutions on violence cases in Nias District, as well as observation and interview methods with local leaders in its ten sub-districts. The feminist perspective is useful to give voice to the "unheard" female actors in a patriarchal society. Findings based on secondary data show that cases of violence in the Nias District from 2009-2016 fluctuated, with a total of 116 cases. The most frequent cases of violence experienced by women are physical violence, as many as 76 cases, sexual violence 31 cases, psychological violence eight cases and economic violence one case. The data collected from the interview and observation are 180 cases. The overall data show that physical violence occupies the highest number (secondary data $65.51 \%$ and primary data $53.88 \%$ ) in the form of a beating received by the wife (domestic violence). The character of women's vulnerability to violence varies in each sub-district and is highly dependent on regional geographic-economic conditions. Therefore, the approach to the resolution of violence in each sub-district may vary. As a conclusion, the practice of violence against women in the Nias District is like an iceberg phenomenon that still needs to be followed up. The research also shows the potential of related institutions partnership, especially encouraged by churches, to end practices of interpersonal violence against women in the Nias District.
\end{abstract}

Keywords: Nias; violence; interpersonal; women; mapping

\begin{abstract}
Abstrak
Penelitian ini membahas pemetaan kekerasan interpersonal terhadap perempuan di Kabupaten Nias, Sumatera Utara. Budaya patriarki di sana memiliki dampak tersendiri pada perempuan. Dengan menggunakan pendekatan pemetaan sosial dan perspektif feminis, data dalam penelitian ini dikumpulkan dengan metode studi pustaka, yakni laporan lembaga-lembaga pengada layanan terhadap kasus kekerasan di Kabupaten Nias, serta observasi dan wawancara kepada para pemimpin lokal di sepuluh kecamatan. Perspektiffeminis berguna untuk memberi suara pada aktor wanita yang "tidak terdengar" dalam masyarakat patriarki. Temuan berdasarkan data sekunder menunjukkan kasus kekerasan di Kabupaten Nias mulai 2009-2016 fluktuatif dengan total 116 kasus. Kasus kekerasan yang paling sering dialami perempuan adalah kekerasan fisik sebanyak 76 kasus, kekerasan seksual 31 kasus, kekerasan psikologis 8 kasus dan kasus kekerasan ekonomi 1 kasus, sedangkan data yang dikumpulkan dari wawancara dan observasi adalah 180 kasus. Data keseluruhan menunjukkan bahwa kekerasan fisik menempati angka tertinggi (data sekunder 65,51\% dan data primer 53,88\%) berupa pemukulan yang diterima istri (KDRT). Karakter kerentanan perempuan terhadap kekerasan bervariasi di setiap kecamatan dan sangat bergantung pada kondisi ekonomi-geografis setempat, sehingga pendekatan untuk mengakhiri kekerasan di setiap kecamatan dapat bervariasi. Sebagai simpulan, praktik kekerasan terhadap perempuan di Kabupaten Nias ibarat fenomena gunung es yang masih perlu ditindaklanjuti. Penelitian ini juga menunjukkan potensi kemitraan institusi terkait, khususnya dimotori oleh gereja-gereja, untuk mengakhiri praktik kekerasan interpersonal terhadap perempuan di Kabupaten Nias.
\end{abstract}

Kata kunci: Nias; kekerasan; antarpribadi; perempuan; pemetaan

\section{Introduction}

Violence is a physical force that could cause the loss of life and lead to many others fatal risks. In many violence cases, women are more prone to expose to violence act. One of the most common 
acts of violence is often performed by husband or people with close relation to the victim. If men are prone to be attacked by strangers or acquaintances, women often received violent act from people in their circle. In Nias Island, the earthquake in 2005 had destroyed the area and created various social problems, including violence on women in Nias. Police and non-governmental organizations recorded that in Nias from 2005-2007, there were 109 cases of violence against women (PKPA 2008). According to Center for Research and Child Protection (PKPA), violence against women in Nias was motivated by a biased interpretation of custom and religion in relation to gender issues. The interpretation affected Nias women in many aspects of their social life.

Socioculturally, Nias society is a group with strong patriarchal culture. Men and women have different position and role with men are the dominant group with a significant role in the society. In opposite, women are always in the background in a group meeting. In a local custom party, women's activities are limited to domestic work such as cooking and cleaning (Zaluchu 2015). Women tend to play the role as an assistant for the men, in a local language known as ngoni-ngoni. Social norms also obliged women to put a high respect to men, the högö or the 'head'.

One of the consequences of patriarchal culture toward Nias women is men's debt payments by women. When a woman becomes a wife of a man, the debt of the man's family will be the responsibility of the woman (Oxfam 2007:6). The debt is the burden of the woman even the transaction was made without the consent or knowledge of the woman (Zaluxhu 2015). The debt also can be delegated to daughters in the household. Women are obliged to work hard to pay off the debt of men in the family; whether the husband's debt or the brothers of the family, if they are not married yet. In Nias, men's interest is perceived as the representation of women's interest due to women's lower position in the social structure.

Women do not have the right to reject the burden delegated to them, which creates a major problem for women. If men's interest could not be fulfilled from the women, men tend to act violently to their women partner, in the form of physical or verbal violence (Zaluchu 2014). Therefore, it is important to stress the right of Nias women in the society.

Types of violence that commonly occurred are sexual violence such as rape which reported to the sectoral police or Departmental (Resort) Police in Nias Island (Lubis 2011). Research from Lubis collected the data from Departmental (Resort) Police, sectoral police and organization that advocates victim of violence, especially for women and children during 2005-2007. The data shows that the number of violence was significantly increased from 25 cases in 2005 to 55 cases in 2006 and reached 109 cases in 2007. Moreover, economic violence was not considered as an act of violence to wife or woman, because family income is regarded as common responsibility for husband and wife to fulfil the household's needs.

At the moment, government and community-based institutions have been established to tackle the problem of violence against women in Nias. Some of them are non-governmental organizations such as Pusat Kajian Perlindungan Anak-Nias, Yayasan Pusaka Indonesia (YPI), and Perkumpulan Sada Ahmo (Pesada) Nias, Caritas Keuskupan Sibolga. In addition, there is also Unit of Service to Women in the Departmental (Resort) Police which its establishment was based on Police of Republic of Indonesia Regulation Number 10 in 2007. The Center for Women and Children Empowerment Pusat Pelayanan Terpadu Pemberdayaan Perempuan dan Anak (P2TP2A) was also established in 33 provinces, separated in 242 cities/regencies (Humas KPPA 2016). All institutions take part in handling report about violence against women in Nias Island.

Programs of those institutions were aimed to reduce the number of violence victims, yet, the data about the case of violence against women from many informants are sporadic. Until the date, there is no data compilation managed by related organizations for women who experienced violence in Nias; whether from a governmental organization such as Religious Court, District or Local Court or national commission on violence against women or initiative from the society or direct report from 
the victims. In addition, there is no clear mapping about violence against women cases in Nias issued by those institutions. Therefore, the development of the issues of violence against women is difficult to observe or to tackle, while the absence of the accurate data could lead to ignorance of violence against women cases.

International convention that still applied as the main references of women protection is the Convention on the Elimination of All Forms of Discrimination against Women (CEDAW), also known as Convention on Women. The international instruments were created in 1979 and adopted by many countries, including Indonesia, to protect the women as a marginalized group. However, CEDAW was not designed to cover unique issue of different women under different circumstances all over the world. Thus, the ratification of CEDAW will not be adequate to protect women. There is a need for a stronger approach with local values as an act of protection of violence against women in different places in the world.

I. Sutherland, V. Sivaarajasingam, and J.P. Shepherd from the Group of Research on Violence. Department of Mouth Surgery, Medicine and Pathology, Medical School of the University of Wales, Cardiff, had researched to find out the violence on society that resulted in the victim treated in Emergency Department to what extent appear on police official record and to identify the prone group that left unrecorded by the police (Sutherland et al. 2002).

The research revealed that the data owned by hospital could provide a unique perspective in analyzing the violent act in society and the record by the police because the hospital has more data and case record compare to the police. Knowledge about the accurate number of crime is severely important for policy making whether in local, regional, or national level. Findings of this research could be used for decision makers to prevent the violent act in society, especially for a group who often left unrecorded in police data as for parties who exposed to violence.

Ministry of Social Service, Ministry of Women Empowerment and Child Protection, National Development Planning Agency, Statistics Indonesia, and United Nations Children's Fund held a survey about violence on children in Indonesia in 2013 with "strong" methodology (Kurniasari 2013). Research sample is boys and girls aged 13-24 in 25 provinces, 108 regencies and 125 districts. From the survey, it was apparent that boys are more often to expose to physical or emotional violence than girls. Interestingly, the survey identified the health condition of boys and girls aged 18-24 who experienced physical and emotional violence before they reached 18 . The result shows that boys who experienced violence tend to smoke and drunk while in girls, they tend to hurt themselves, use drugs, and attempted to suicide. Due to the approach used was not a gender-sensitive approach, the number found could not be discussed any further in this research.

Annual record on violence against women from National Committee on Women in 2016 summarized the violence cases experienced by women that were handled by service providers in the last one year. Most violence performed in the form of domestic violence/personal relation amounted to 11.207 cases (69\%); 4.303 cases of physical violence (38\%), 3.325 cases of sexual violence $(30 \%), 2.607$ cases of emotional violence; and 971 cases of economic violence $(9 \%)$. Violence in the community recorded up to 5.002 cases $(31 \%)$ and there is violence that supposed to be the responsibility of the state such as marriage certification forgery, unrecorded marriage, human trafficking, and persecution by police.

In Western Sumatera, NGO called WCC Nurani Perempuan noted 85 cases were reported in 2015 (Chaniago 2016). 40 cases of them are sexual violence, 35 cases are domestic violence and 4 are human trafficking. $67 \%$ of violence performed to children while $33 \%$ of adult experienced it. Highest cases of violence in Indonesia happened in Papua (NN 2015). Sylvana Apituley, the leader of Papua working group of National Committee of Women stated that the violence happened in almost every area in Papua in the form of sexual, physical, and emotional violence. The perpetrators were not only civilian but also security officials. Annual mapping in every region, therefore, is important for the development of violence against women cases could be understood and the violence characteristic 
can be shown. This is a practical step in order to cut the trend of violence against women, especially in Nias until the present time. By focusing on Nias, Nias women are expected to be the biggest recipient of the output of this research. This article will also provide understanding about the form of violence that frequently experienced by women, also for the partner and family, and men, in general, to realize the women's vulnerability to be exposed to violence in their environment.

By using the sample in one area in Nias Island and learning the development of interpersonal violence cases toward women during 2009-2016, researchers expected to achieve a description about the type of interpersonal violence experienced by Nias women. Given the background, the research aims to answer the question of how is the mapping of interpersonal violence cases against women in Nias in the last 8 years. Specifically, the research aims to: firstly, know the number of interpersonal violence against women cases collected by related institutions in Nias Regency as the area of research in 2009-2016. The second purpose is to know the number of interpersonal violence against women cases in every district in Nias Regency in 2009-2016. The last aim is to identify the characteristic of violence against women cases in Nias during the period.

\section{Research Method}

Based on Suharto (n.d.) this research applied social mapping approach to obtain a systematic description of interpersonal violence against women profile in Nias during 2009-2016 by collecting related data. Social mapping used in community development in order to improve society by taking a collateral action, as mentioned by Twelvetress (1991:1) that defines community development as "the process of assisting ordinary people to improve their own communities by undertaking collective actions".

Types of data used in this research are primary and secondary data. Secondary data are gathered by mapping of violence against women data received by service provider institutions in the district of Nias. Primary data are gained by observation and interview to local figures such as pastor, the local midwife, nurse, head of the village, head of Family Welfare Movement, Village secretary, and the wife of the village secretary to collect information about interpersonal violence against women. Informants were chosen by random sampling.

Data that gathered by the two methods were compiled and rechecked to avoid double counting if same cases were found. The final result of data compilation provided in table or graphic using Microsoft Excel as quantitative analysis tools. Data were further interpreted to address the research problem. Analysis and interpretation of information from the informants were conducted separately. Researchers use the data to reflect on and build upon knowledge for the voice that had been ignored (Doucet \& Mauthner 2006:41). Thus, the description of the types and meaning of interpersonal violence against women in Nias Regency and the trend during 2009-2016 could be acquired.

\section{Result and Discussion}

Definition of violence according to World Health Organization (WHO) Global Consultation in 1996 in term of violence and health is "the intentional use of physical force or power, threatened or actual, against oneself, another person, or against a group or community that either result in or have a high likelihood of resulting in injury, death, psychological harm, maldevelopment, or deprivation" (WHO 1996:2-3). The definition stressed the use of force and power to an individual or a group of people executed intentionally which cause injury, death, psychological impact, imperfect development, or loss. The use of the term of 'force' also included intimidation, domination and threat, such as abandonment and negligence.

World Health Assembly resolution (1996) classified violence into three types: self-directed violence; interpersonal violence; and collective violence (Krug et al. 2002:6). This research highlights the interpersonal violence. The violence is different from domestic violence. Perpetrators in interpersonal violence encompass a very board scope; not limited to the private relation. The possibility of violence against women in the District of Nias which is not performed by family, partner or domestic partner encouraged researchers to focus on interpersonal violence instead of another type of violence. 
Interpersonal violence is categorized into four types: physical violence, sexual violence, psychological or psychic violence, and economic violence in the form of deprivation and negligence. United Nations defined physical violence as follows:

"Physical violence consists of acts aimed at physically hurting the victim and include, but are not limited to, pushing, grabbing, twisting the arm, pulling the hair, slapping, kicking, biting or hitting with the fist or object, trying to strangle or suffocate, burning or scalding on purpose, or attacking with some sort of weapon, gun or knife." (UN 2015:143).

Physical violence in United Nation definition is not only limited to creating physical wound to victim with an empty hands like hitting, slapping, pulling hair, but also using weapon such as gun and knife. Violence performed by an intimate partner also covered sexual violence, which defined as:

\begin{abstract}
"Any sexual act, attempt to obtain a sexual act, unwanted sexual comments or advances, or acts to traffic, or otherwise directed, against a person's sexuality using coercion, by any person regardless of their relationship to the victim, in any setting, including but not limited to home and work" (Krug et al. 2002:149).
\end{abstract}

The definition above indicates sexual measure on the verbal form such as seducing words or in a non-verbal form such as stare which unwanted by the recipient under any circumstances in any place is defined as sexual violence. According to WHO, the victim of domestic abuse also exposed to psychological and health risk (Krug et al. 2002:149). Physical impact endured by the victim related to reproduction health and psychological situation involves mental disruption of the victim after the experienced undesirable act.

In the scope of psychological violence, United Nations divide violence into two types: emotional abuse and controlling behaviour. Emotional abuse is defined as "insulting or making a woman feel bad about herself, belittling or humiliating her in front of others, deliberately scaring or intimidating her, threatening to hurt her or others she cares about" (UN 2015:152). There are three keywords in the type of violence: insulting, humiliating, and intimidating. Insult could occur in a verbal or nonverbal form that aims the recipient of the action feels discouraged; humiliation involves the act of discriminating and stereotyping. Intimidating means the act of threatening and scaring people until they feel insecure which ignites the feeling of worry and terrifying thought. Controlling behaviour is defined as:

“..isolating a woman by preventing her from seeing family or friends, monitoring her whereabouts and social interactions, ignoring her or treating her indifferently, getting angry if she speaks with other men, making unwarranted accusations of infidelity, controlling her access to health care, education or the labour market" (UN 2015:152).

Given the definition, controlling behaviour to women is not always performed in a physical manner, yet it could create an emotional wound such as the absence of freedom for women to decide to whom they interact and socialize. It could also mean the absence of affection and attention they are supposed to receive from their family and partner or access to acquire their rights such as access to the economy, health care and education. Finally, economic violence defined by United Nation as:

“..economic violence can involve denying access to the property, durable goods or the labour market; deliberately not complying with economic responsibilities, thereby exposing a woman to poverty and hardship; or denying participation in economic decision-making" (UN 2015:153).

Even though the definition only refers to adult women, the definition of WHO stated that economic violence could involve all members of the family. Referring the definition by WHO, the keywords are 'deprivation' and 'negligence' experienced by children, wife, or husband by the unfulfillment of daily needs; enforcing women or kids to accomplish domestic works, or prohibition for women to work. 


\section{The number of interpersonal violence against women in Nias 2009-2016}

Secondary data acquired from 2009-2016 shows that interpersonal violence against women cases in the district of Nias were 116 cases. In 2016, data gathered only from January until August 2016 which makes the data is insufficient to be compared with the data from 2009 until 2015. Based on the secondary data, the violence cases in the district of Nias were fluctuating. Even though violence cases in Nias were handled by service provider institutions, the criminal sector and civil justice sector, the data shows that intersectoral cooperation in resolving violence against women cases in Nias was not effectively performed yet. The description below will discuss finding from secondary data based on the resource.

Based on the acquired data, District of Gunungsitoli Court was the institution that provides largest data, reaching 52\% from all 116 cases. The rank was followed by PKPA Nias with $19 \%$ of data, UPPA Nias sectoral police with 15 percent of data and $P 2 T P 2 A$ with 11 percent. An institution that provides the least data is Religious Court of Gunungsitoli with only $3 \%$ of data. Information openness adopted by the institution in a local court in Indonesia according to Decision of The Chairman of the Supreme Court 144/KMA/SK/VII/2007 about information openness in court has positively contributed to the mapping of violence against women cases. However, the question about settlement and data mapping of violence cases in District of Nias remain unresolved; such as the limited human resources, the lack of road infrastructure, and people unwillingness to report violence cases that they experienced.

Data from the Gunungsitoli District Court revealed that $69 \%$ of violence occurred in the form of physical violence and recorded as the highest cases reported. Sexual violence placed second with $26 \%$ of reports and psychological violence reached $5 \%$ of total violence reported. The type of violence which left unmonitored was economic violence due to the type of violence is not yet categorized as a crime. Secondly, different from District of Gunungsitoli Court, Gunungsitoli Religious Court did not provide adequate data of violence against women cases. Compared to data gathered by National Commission on Violence against Women in 2016, Religous Court is the institution that provides most data on the national scale. The absence of significant data in Religious Court of Gunungsitoli was possibly because most of Gunungsitoli people are Christian.

Based on the third source, data from Nias Sectoral Police recorded two types of violence against women during 2009-2016; they were physical and sexual violences. $82 \%$ of the violence cases recorded was physical or equal to 14 cases while there were three cases of sexual violence or $19 \%$ of the total of violence cases. Psychological and economic violences were left unrecorded.

Fourth is discussion originated from the data gathered by P2TP2A. P2TP2A of the District of Nias is the only P2TPA in Nias that serves other areas such as Gunungsitoli, district of West Nias, District of South Nias and District of North Nias. However, P2TP2A of the District of Nias only contributed $11 \%$ of data from total 116 cases of violence against women in Nias. From $11 \%$ data provided by $P 2 T P 2 A, 87 \%$ or 14 cases are physical violence and $13 \%$ or two cases are sexual violence.

The last discussion is about data gathered by $P K P A$ Nias as one of Non-Governmental Organization focused on women and child right issues. PKPA Nias was established and effectively operated in 2006 after Nias earthquake in March 2005. Based on the data from PKPA Nias, sexual violence is the highest type of violence recorded as many as $53 \%$ or 10 cases. There were six cases of physical violence of which percentage was $32 \%$. Psychological violence placed third with $16 \%$ of all cases or 3 cases. 19 cases recorded as cases which involved underage women. Based on the secondary data, 116 cases were handled and recorded differently by each institution, whether service provider institutions from criminal sector or civil justice. 61 cases recorded by the District of Gunungsitoli Court were completed with perpetrators are jailed. Three cases handled by Religious Court of Gunungsitoli also have been decided.

From all violence cases at the court level, victim support system remains unknown. Whereas the existence of those service provider institutions also the crime sector and civil justice institutions has a great potential to synergize one another in order to resolve much violence against women cases to the handling of victims across sectors. Until the date, there is no proper coordination with gender- 
sensitive measure between institutions in crime sector and civil justice to handle violence against women cases in Nias, starting from the report, case handling and assistance to victims, until the case termination.

Reports revocation by the victim or the family member also occurred frequently due to the feeling of embarrassment if a case of violence were investigated in the public space. Violence against women issues in Nias is not considered as social problems. It is regarded as something trivial or personal issues of a family. Moreover, patriarchic culture in Nias gives no access for women to communicate or report violence cases they experienced to their relatives or to officials. The culture is internalized into Nias phrase hold in the society: "sökhi mate moroi aila" (death is better than shame).

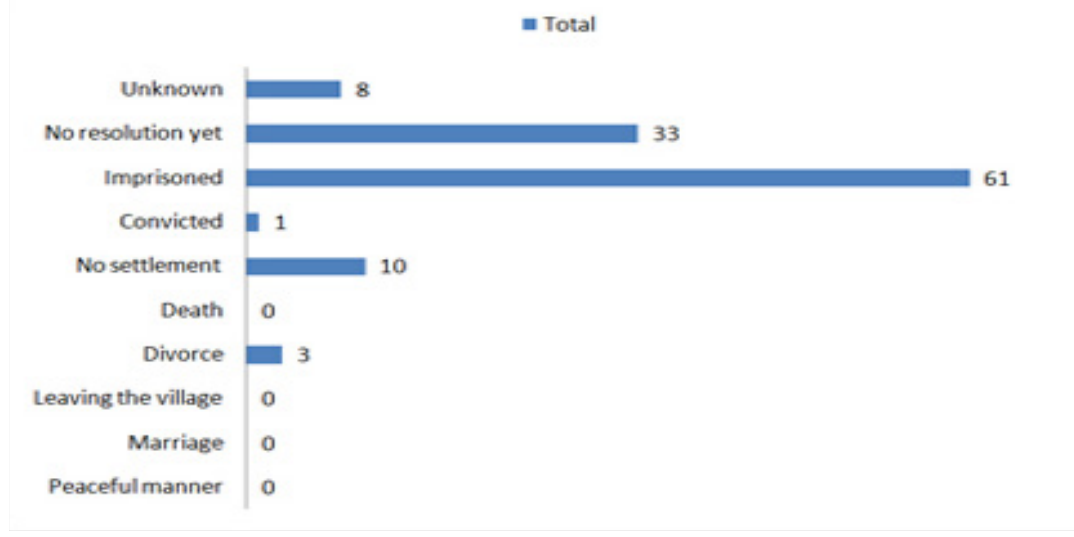

Graph 1.

Interpersonal violence against women settlement 2009-2016

Source: Research secondary data

Victim unwillingness to report their cases could also because of no availability of "fund" for their cases to be handled by the official. According to the chief of PKPA Nias, Khairuldani, many cases of violence left unreported were because the victims chose to resolve "peacefully" (Interview, 27 October 2016). Various reasons motivated society to take peaceful manner to resolve the conflict such as 1) Police officials in several areas tend to victimize the victim; 2) family member of the victim choose to conceal the case to avoid disgrace.

Based on primary data collected by researchers, almost all interpersonal violence against women cases in Nias were resolved 'peacefully', even though many problems linger in the settlement. Many informants stated that their willingness to agree to the peaceful settlement was because they were forced by custom agreement, if not forced by the family member. Once the agreement achieved, the case was considered resolved. No measure taken for victim recovery, no conflict reconciliation performed properly, and no effort to make perpetrators aware of their fault only because the custom measure was taken as a way to achieve resolution.

Achieving peace also attempted by Churches. Such manner is proved to be more effective to cut the cycle of abuse received by the victim because almost every Church provide a community that involves victim, perpetrator, or family member as an accountability/responsibility medium of each member. Those efforts also performed by one pastor through Youth Movement to anticipate teenagers' shift of lifestyle due to the use of internet and mobile phone that could lead to an easier access for sexual violence to teenage girls. Marrying victim of sexual abuse has become something common in the society, more common than leaving the village. Divorce is considered as disgrace which explains the low number of cases that resolved by separation or leaving the village. Many cases that have not yet resolved also appeared frequently.

Based on the informant types, researchers gained most data from the Church $(72.22 \%)$. The role of Church in Nias could not be overruled since the institution is the most accessible institution for the victim of domestic abuse. Churches in Nias are equally spread in various areas, reaching the remote 
ones. Churches are also more open and sensible in discussing the violence against women cases and acknowledge violence as something that should be handled.

Table 1.

Mapping the settlement measures (2009-2016)

\begin{tabular}{llccccccccc}
\hline No & $\begin{array}{c}\text { Cases settlement } \\
\text { method }\end{array}$ & $\mathbf{2 0 0 9}$ & $\mathbf{2 0 1 0}$ & $\mathbf{2 0 1 1}$ & $\mathbf{2 0 1 2}$ & $\mathbf{2 0 1 3}$ & $\mathbf{2 0 1 4}$ & $\mathbf{2 0 1 5}$ & $\mathbf{2 0 1 6}$ & Total \\
\hline 1 & Peaceful manner & 21 & 16 & 1 & 8 & 3 & 5 & 19 & 25 & 98 \\
2 & Marriage & & & & & 1 & 4 & 2 & 1 & 8 \\
3 & Leaving the village & & & & 1 & & & & & 1 \\
4 & Divorce & & & 1 & & & & & & 1 \\
5 & Death & & & & & & 1 & & & 1 \\
6 & No settlement & 1 & 1 & 4 & 3 & 1 & 11 & & 5 & 22 \\
7 & Unknown & Source: Research primary data & & & \\
\hline & &
\end{tabular}

Researchers gained second most significant data from the villagers. They were proven substantial in cutting the violence cycle if they have adequate knowledge and skill in handling the problem. People in Botomuzöi regency shared valuable information to researchers about violence against women cases in the regency. People who tend to be afraid in facing officials and scared of external parties are frequently found by researchers, particularly in regencies that located far from the district center. Medical personnel also contribute significant information to the researchers, particularly in personal information such as domestic abuse and sexual abuse that was taboo to be publicly discussed. For instance, in Somölö-mölö the sexual abuse in enforcing women to get pregnant of boy is high. Unfortunately, the medical personnel only provide medical assistance to the victim because they have only limited information about violence against women.

Village officials in regency that were visited by researchers have a great potential in handling violence against women cases in their area. All officials are aware with violence against women cases in their administrative area, but they did nothing to settle the problem. An official even asked his wife to answer questions proposed by researchers as if the question should be addressed by women because it is women's problem. While the husband, who works as village official, actually has a wider access to information; including how to handle violence against women cases.

\section{Characteristic of interpersonal violence against women in the District of Nias}

Based on research secondary data, physical violence occupied first place with total 76 cases or $65 \%$ of total cases. Sexual violence ranked second with 31 cases or $27 \%$ of cases. Psychological violence ranked third with $7 \%$ or 8 cases and there was only $1 \%$ of economic violence case or equal to 1 case. The type of psychological violence according to Kleinman (2000) could occur in the form of ideology, words, behavior, non-verbal communication that indicates stereotype, hegemony, humiliation, stigma, or alienation of women as a part of social structure. In the context of District of Nias, psychological violence endured by the women was humiliation and domination. There were 4 cases of humiliation and 4 cases of domination. In this research, escaping women were categorized as domination because women did not experience sexual harassment in any form. Another domination cases are underage children trafficking (two cases) found in Gidö Regency. The case was categorized as domination because there was power abuse executed by parents, in this case is a father, who is supposed to take care, educate, and fulfil the children's daily needs.

Based on the secondary data gathered from five sources, there was little to no reports on economic violence. There was only one case from a total of 116 cases recorded as economic violence. The data acquired from Gunungsitoli Religious Court based on divorce cases or divorce proposed by the wife because husband did not fulfil family needs. 


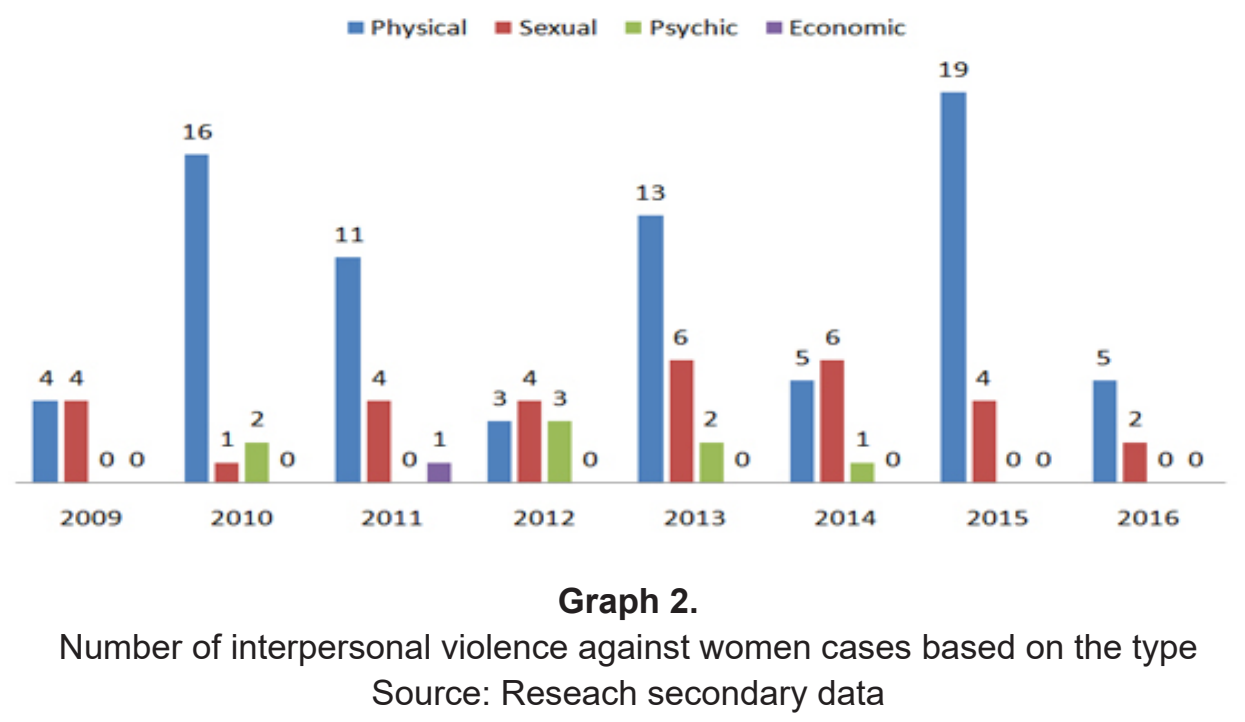

Data of interpersonal violence against women during 2009-2016 based on observation and interview in ten regencies in Nias was different from the secondary data because economic violence occurred as the most frequent type of interpersonal violence cases after physical violence. Because the data was taken since the end of October until early of November, it is important to be noted that data gained by researchers are limited up to October 2016. The number of primary data from observation and interview reaches 180 cases (2009-2016). The violence categorized into physical violence (beating, persecution), sexual violence (enforcement of sexual intercourse and female reproduction control), psychological violence (threatening, wound due to dysfunction of social relationships in the family), and economic violence (negligence by parents or husband). Physical violence ranked highest with 97 cases (53\%) during the past eight years, followed by economic violence with 35 cases $(19.4 \%)$. There was 34 cases of sexual violence (18.8\%) and $7.7 \%$ of psychological violence.

Interpersonal violence against women cases found based on observation and interview were fluctuating. All cases collected from observation and interview was not resolved in the legal measure. Thus, the number fluctuation does not indicate awareness of victim or family member to report their case or to express it in public space or before the law. Number in the Figure 3 describes the reality of women in Nias and their vulnerability for any type of violence in the form of physical, economic, sexual, or psychological.

Each type of violence against women is inseparable. Even in Figure 3, the number of psychological violence is low, this is because researchers should count one case happened to each victim (to avoid double counting to the amount of victim). In reality, a victim of physical violence will most likely experience economic and psychological violence as well. The psychological violence, occurred as a threat and the loss of women dignity in the eye of the perpetrator or family, is almost definitely to be experienced by the victim of another type of violence: economy, sexual, and physical.

Based on the district, interpersonal violence against women cases in Nias shows three regencies that recorded highest number of violence, namely Bawölato (20,56\%), Somölö-mölö (17,2\%), and Botomuzöi (14,44\%). From the three regencies, Somölö-mölö is the regency which located furthest from the center of the district. Road access for four-wheeled vehicles is proper, but the area is not yet covered by electricity wholly. In other words, the number of unrecorded interpersonal violence against women cases in Nias Regency are not depended on each district's development.

Physical violence against women also highly associated with economic negligence by the husband. In Hiliduho (2016), a husband who does not provide the needs of the family also did violent act to the wife, especially when the husband was under the influence of alcohol. There are several cases where the husband could not endure the economic pressure and choose to leave the wife. The situation is left unrecorded by any institution, even though the Church knows about the information. 


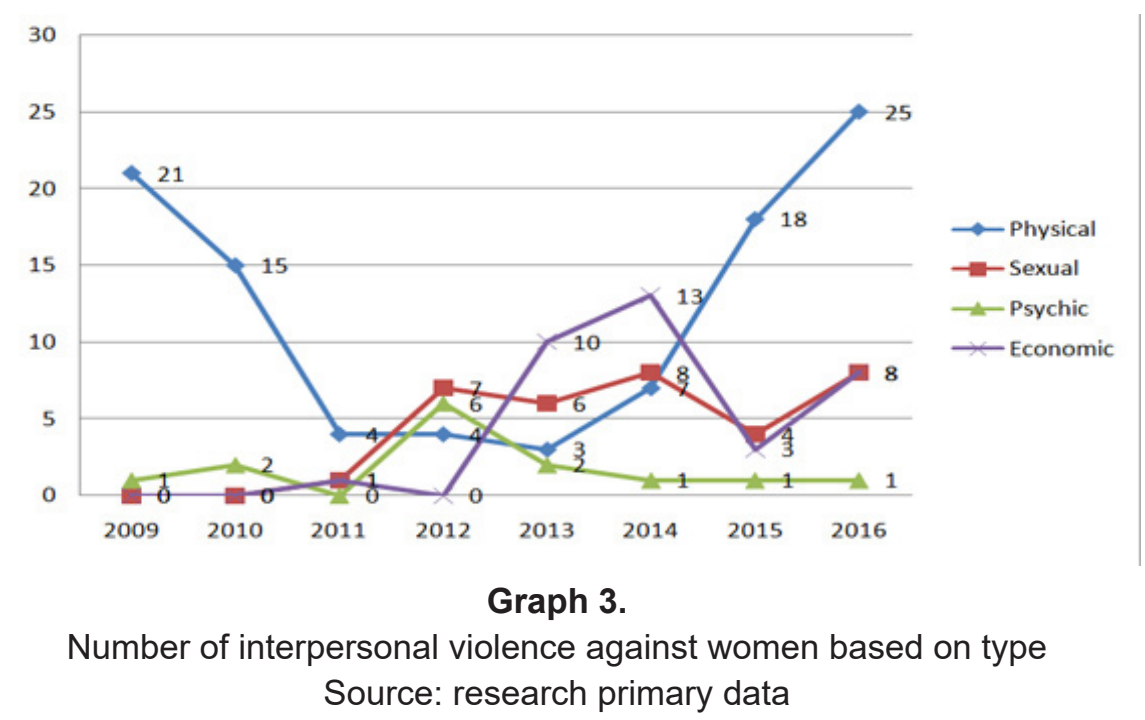

Primary and secondary data proves that girls are the most vulnerable group to experience violence against women compared with another group. If victim happened to be "lucky", they will be supervised and handled by service provider institutions, crime sector, or civil justice institution. However, most women recorded in this part have common experience: they never receive proper case handling and support for the abuse they experienced.

An institution like $P 2 T P 2 A$ in Nias, that should have been active in measuring and resolving violence against women cases, in fact often forward the cases to a non-governmental organization such as PKPA Nias and Pesada Nias. On the other hand, Nias Sectoral Police had failed miserably to handle the problem because they do not gain trust from victim and family member of the victim due to their system of work, particularly in inefficiency and long administrative process before a case could be proceed. There are several polices who known as taking benefit from the victim and the family which increase the unwillingness of victim to report their case to the police.

\section{Conclusion}

Violence against women in Nias is the tip of the iceberg. Many cases left unrecorded and resolved without paying attention to women sensitivity and the patriarchic culture in Nias. Physical violence against women in Nias recorded the highest number during 2009-2016 (secondary data $65.51 \%$ and primary data $53.88 \%$ ). The helplessness of victim leads them to the inability to cut the violence cycle. For instance, economic violence such as negligence and physical violence are considered resolved because women do not even realize that they are being suppressed. Under this situation, Church is the institution that could play a massive role in reducing the number of violence against women cases; given the majority of Nias people is Christian. Furthermore, Christian values are strongly rejected violence against women. On the other hand, research finds that there is a significant role played by the Church for its regular meeting and serving. This institution has access to the people in the society and is closer to women so that Church could become the institution spreading the information and raising awareness about violence in Nias. Serving mechanism in Church could be adopted as an instrument to cut the violence chain. This research also encouraged Church to strategically respond the high number of violence against women in Nias through cooperation with the Governmental institutions and NGOs such as law institutions, healthcare institutions, and the other type of service provider institutions.

\section{Acknowledgement}

Researchers would like to express highest gratitude for the support given by Universitas Kristen Indonesia in completing this research. Specifically, researchers would also like to thank local officials for facilitating data collection in 10 regencies in Nias. Without assistance and commitment from local officials also their familiarity with research terrain, data collection would be impossible to be accomplished. 


\section{References}

Chaniago F (2016) Kekerasan terhadap perempuan masih tinggi. [Accessed 2 September 2016]. http://padangmedia.com/kekerasan-terhadap-perempuan-masih-tinggi/.

Doucet A \& Natasha SM (2006) Feminist Methodologies and Epistemology. In: CD Bryant \& DL Peck (ed). Handbook of $21^{\text {st }}$ Century Sociology. California: Sage.

Humas KPPPA (2016) Fluktuasi jumlah kasus kekerasan perlu diwaspadai. [Accessed 2 September 2016]. http://www.kemenpppa.go.id/index.php/page/read/29/188/press-release-fluktuasijumlah-kasus-kekerasan-perlu-diwaspadai.

Khairuldani (2016) [Personal communication] 27 October.

Komnas Perempuan (2016) Kekerasan terhadap perempuan meluas: Negara Urgen hadir hentikan kekerasan terhadap perempuan di ranah domestik, komunitas, dan negara. Catatan Tahunan tentang Kekerasan terhadap Perempuan. Jakarta, 7 March.

Komnas Perempuan (2014) Bentuk-bentuk Kekerasan Seksual. [Accessed 30 November 2016]. http://www.komnasperempuan.go.id/wp-content/uploads/2014/12/15-Bentuk-KekerasanSeksual1.pdf.

Kleinman A (2000) The Violences of Everyday Life: The Multiple Forms and Dynamics of Social Violence. Dalam: V Das, A Kleinman, P Ramphele, \& P Reynolds (eds). Violence and Subjectivity. Berkeley: University of California.

Krug EG, Dahlberg LL, Mercy JA, Zwi AB, \& Lozano R (eds) (2002) World Report on Violence and Health. World Health Organization. Geneva: World Health Organization.

Kurniasari A, Wismaayanti YF, Irmayani, Husmiati, Widodo N, \& Susantyo B (2013) Ringkasan hasil survey kekerasan terhadap anak Indonesia tahun 2013. Penelitian kerja sama antara Kementerian Sosial, Kementerian Pemberdayaan Perempuan dan Perlindungan Anak, Badan Perencanaan Pembangunan Nasional, Badan Pusat Statistik dan Unicef Indonesia. [Accessed 2 September 2016]. http://puslit.kemsos.go.id/upload/post/files/4fb404d806e55b69e7fa7d4106344914.pdf.

Lubis M (2011) Penelitian kekerasan terhadap anak perempuan dan pernikahan dini di Pulau Nias. Dokumen Pusat Kajian dan Perlindungan Anak (PKPA) Nias. [Accessed 2 September 2016]. http:// konsillsm.or.id/kekerasan-terhadap-anak-perempuan-pernikahan-dini-di-pulau-nias/?lang=en.

Pusat Kajian dan Perlindungan Anak (2008) Penelitian kekerasan terhadap perempuan dan pernikahan dini di Kabupaten Nias: Perempuan Nias merajut mimpi. Medan: PKPA.

Resolusi Majelis Umum 48/104 (1993) Deklarasi tentang Penghapusan Kekerasan terhadap Perempuan. [Diakses 2 September 2016]. http://www.un.org/documents/ga/res/48/a48r104.htm.

Suharto E (Tanpa Tahun) Metode dan Teknik Pemetaan Sosial. [Accessed 2 September 2016]. http:// www.policy.hu/suharto/modul_a/makindo_18.htm.

Sutherland IV, Sivarajasingam, \& Shepherd JP (2002) Recording of community violence by medical and police services. Injury Prevention 8:246-247.

N.N. (2015) Petaka Perempuan Papua. Artikel Berita Jaringan Kerja Rakyat Papua tanggal 28 Januari 2015. [Accessed 16 September 2016]. http://www.jeratpapua.org/2015/01/28/petakaperempuan-papua/.

Twelvetrees A (1991) Community Work. Second Edition. London: Macmillan Education Ltd.

United Nations (2015) The World's Women 2015: Trends and Statistics. New York: United Nations Publications. 
United Nations (2006) Ending violence against women: From words to action. Study of the SecretaryGeneral. New York: United Nations Publications.

World Health Organization (WHO) (1996) Violence: A Public Health Priority. Global Consultation on Violence and Health. Geneva: WHO.

Zaluchu F (2014) Jujuran dan posisi perempuan Nias. [Accessed 2 September 2016]. http://niasbangkit.com/2014/02/jujuran-dan-posisi-perempuan-nias/.

Zaluchu F (2015) Tragedi Perempuan Nias, sampai kapan? [Accessed 2 September 2016]. http:// nias-bangkit.com/2015/05/tragedi-perempuan-nias-sampai-kapan/. 